\title{
The Absence of Democracy in Aboriginal Self-Governance Policy
}

Gina van den Burg, McMaster University

The protracted history of Aboriginal governance policy is ripe with frustrations among First Nations peoples and Canadian governments, the most pronounced aggravation being the federal government. Substantial resistance from Aboriginals often marks each new policy the government introduces. New policies often maintain the paternalistic attitude inherent in government initiatives, which has been very difficult for Aboriginal organizations to eradicate. Although Aboriginal governance policy is currently progressing towards a quasi-cooperative form of policy-making on both sides, this particular policy area continues to encounter significant disparities between policy actors within the Canadian government and Aboriginal organizations. Differences throughout the entire policy process hinder effective policy-making from agenda-setting/problem definition to the outcome/evaluation.

This research paper can help explain the reasons behind the continuous failures of such government policies and how the living conditions of Aboriginals can be improved through recognition of their right to self-determination. First, I will detail the evolution of Aboriginal governance policy and the difficulties it is confronted with today. In the second section, I will explore the roles and salience of specific policy actors involved in this particular area. An analysis of the differing ideologies and policy goals will be outlined in the third section. I will makes use of path dependency theory to aid in the explanation for the relatively constant policy path that has transpired over the past century. In the fourth section, I will provide methods for improving the role of Aboriginals in the policy-making process. Such improvement is important for diminishing the often overbearing position of the government in Aboriginal governance affairs. I will argue that treaty federalism provides the most reasonable and equitable procedure for this case. Lastly, I will describe the primary and secondary sources utilized, followed by a brief explanation of their importance in the overall presentation of the paper.

Aboriginal governance policy can be separated into three different policy fields. ${ }^{1}$ The first includes broad yet important policy areas, such as international trade and customs, which may affect Aboriginals but are largely ignored in the policy process. The second policy field incorporates issues that are central to the interests of Aboriginals, but which only affords them a semi-involved role in the consultation and decision-making processes. Such examples are parks

\footnotetext{
${ }^{1}$ See Appendix A
} 
and environmental protection. The third and most relevant policy field includes federal and provincial policy in relation to specific Aboriginal issues, such as the governments' responses to said treaty violations, most especially those pertaining to self-government treaties. ${ }^{2}$ This last policy field has remained one of the more constant issues on the agendas of First Nations; however, only within the last three decades has self-government for Aboriginals been on the federal government's agenda.

\section{I: Policy Continuity}

Understanding the evolution of Aboriginal policy is of the utmost importance since almost every new policy introduced by government is a derivative of past policies. Each policy attempts to make reforms on past policies, avoid previous mistakes or utilize old policies as guidelines. Aboriginal governance policy has been rather unstable over the past three centuries. It often emerges in sporadic periods, usually surrounding Constitutional issues. Students of public policy may identify this behaviour as punctuated equilibrium-i.e., the stagnation of a policy until a crisis situation unexpectedly appears, but gradually levels out to a less serious tone as the target population learns to adapt. This description is only partially accurate. Many federal policies have emerged uncoordinated, spontaneous, and often contradictory. Consistently Aboriginal governance policy has remained a "collage of policies" rather than a constant policy framework with explicitly defined goals. ${ }^{3}$ More precisely Aboriginal governance policy has continuously shifted from assimilation to recognition back to assimilation. This will be exemplified in greater detail later in the paper. Additionally, numerous governance policies rely on the specifics established in the restrictive Indian Act which the government refuses to more than symbolically reform. ${ }^{4}$

The first policy adopted by the federal government was the Royal Proclamation of 1763. This Act prohibited the occupation or sale of land specifically reserved for Indians without the direct consent of the Crown. It also stipulated that the Crown would maintain its protection over Indians from being disturbed by external governing bodies or citizens. Implicitly, no other agent, including the Governor or Commander in Chief of the time, can create or enforce laws on the

\footnotetext{
${ }^{2}$ Royal Commission on Aboriginal Peoples, Soliloquy and Dialogue: Overview of Major Trends in Public Policy Relating to Aboriginal Peoples, Public Policy and Aboriginal Peoples 1965-1992, (Ottawa: Minister of Public Works and Government Services Canada, 1996) p. 39.

${ }^{3}$ Sally Weaver, 'Federal Difficulties with Aboriginal Rights Demands', in Boldt, Long and Bear (ed) The Quest for Justice, (Toronto: University of Toronto Press, 1985) p. 139.

${ }^{4}$ Frank Cassidy and Robert L. Bish, Indian Government: Its Meaning in Practice, (Halifax: The Institute for Research on Public Policy, 1989), p. 19-20.
} 
lands belonging to the allied Indians. The Royal Proclamation incorporated these requests from First Nations with every intention to implement them as a sign of their gratitude for the numerous Indian alliances formed with the British during the French-English Wars in North America. ${ }^{5}$ The Act would become the basis for the 1876 Indian Act.

With the creation of the Dominion of Canada many of the British Crown's responsibilities over Indian policy were handed over to the new Canadian government. It was expected that the new government would continue to respect Indian lands, government and treaties. In 1876 the federal government instituted the Indian Act which was intended to provide greater protection from abuse and obtrusive settlers and to implement the obligations of treaties, royal instructions and the Royal Proclamation into federal law. Still, the federal government "increasingly took a broad view of being able to legislate for the 'Indians' on matters not delegated to it by the treaties" ${ }^{\prime \prime}$ resulting in a distorted policy of assimilation. In several areas the Act does fulfill its protectionist objective but it simultaneously eradicates the independence of First Nations by introducing a significant role for the Governor-in-Council in Aboriginal affairs. The primary goal of this policy was not necessarily protection, but rather "to prepare [First Nations peoples] for a higher civilization by encouraging [them] to assume the privileges and responsibilities of full citizenship". ${ }^{7}$ After a century and a half the federal government continues to maintain the same policy goal of assimilation by refusing to safeguard Aboriginal autonomy from external abuse and interference, and this will continue so long as the Indian Act remains unaltered. What is needed is revision. The complete annihilation of the Act is certainly not a prerequisite in the acquisition of Aboriginal self-government. In fact, it can have the reverse effect by accelerating the process of assimilation. This was the experience with the infamous 1969 White Paper on Indian Policy.

Pierre Trudeau's dreams for a just and equal society conflicted with First Nations' treaties designed to preserve their uniqueness and special privileges bequeathed to them for centuries. Therefore his solution was to eliminate any precursor of difference within Canadian society including the Indian Act, which set First Nations apart from the rest of the Canadian populace. His goal, with the assistance from the Minister of Indian Affairs at the time-Jean Chrétien - was to integrate Indians into Canadian society so they could enjoy all the benefits of Canadian citizenship. The elimination of the Indian Act would end the distinction between status

\footnotetext{
${ }^{5}$ Donna Hawley, 1990 Indian Act, (Toronto: Carswell Company Limited, 1990), p. 23-27.

6 James Youngblood Henderson, 'Empowering Treaty Federalism', (Saskatchewan Law Review vol. 58, 1994), p. 276-277.

${ }^{7}$ Richard H. Bartlett, The Indian Act, $2^{\text {nd }}$ ed., (Saskatoon: University of Saskatchewan, 1988), p. 2
} 
and non-status Indians and disregard any previous treaties or legislation that identified Aboriginals' right to self-government. The quick and unanticipated response from First Nations political organizations resulted in the termination of the policy. ${ }^{8}$ Although Pierre Trudeau continued to sustain his strong stance on individualism and equality, he interestingly enough recognized separate rights for First Nations in the Constitution Act of 1982.

The inclusion of Aboriginal governing rights was not necessarily a matter of choice for Trudeau. It was not until several Aboriginal organizations lobbied the Queen and British Parliament to cease the patriation process that such rights were considered. The adoption of sections 25 and 35 of the Constitution Act 1982 symbolized a significant step forward for Aboriginal self-government, because for the first time in Canadian history Aboriginal and treaty rights were entrenched in the constitution. Section 25 asserted that the newly adopted Charter of Rights cannot supersede Aboriginal treaty rights, and section 35 verifies the existence of Aboriginal and treaty rights. ${ }^{9}$ Nevertheless, the Canadian government retained the view that these rights can be negotiated, as was evident during Mulroney's endeavor to amend the constitution.

Aboriginal peoples question why negotiations must occur when they believe their needs are clearly outlined in treaties and the Constitution. Yet, the exclusion of Aboriginals in constitutional negotiations forced them to reconsider this thought. In the 1987-1990 Meech Lake Accord, discussions concentrated on improving the partnership between English and French Canada and ignored the historical role of Aboriginal peoples in building Canada. This omission was costly on the part of the federal government. Elijah Harper, an Aboriginal occupying a seat in the Manitoba legislature, objected to the idea of recognizing Quebec as a distinct society but not Aboriginals' right to self-government. The delays Harper instigated resulted in the ultimate expiry of the Accord. ${ }^{10}$ The Mulroney government now had to ensure that Aboriginal selfgovernment issues would not be neglected.

Thus, the following constitutional round in 1992 included Aboriginal political organizations and other groups of First Nation citizens in the discussions. The Charlottetown Accord would finally entrench Aboriginals' inherent right to self-government in the Constitution

\footnotetext{
${ }^{8}$ Frank Cassidy and Robert L. Bish, Indian Government: Its Meaning in Practice, (Halifax: The Institute for Research on Public Policy, 1989), p. 8.

${ }^{9}$ Radha Jhappan, 'The Federal-Provincial Power-grid and Aboriginal Self-Government' in Rocher and Smith (ed). New Trends in Canadian Federalism, (Peterborough: Broadview Press, 1995), p. 172-3.

${ }^{10} \mathrm{~J}$ Anthony Long \& Katharine Chiste, 'Aboriginal Self-Government', in Bickerton \& Gagnon (ed) Canadian Politics $2^{\text {nd }}$ Edition, (Peterborough: Broadview Press, 1994), p. 227.
} 
and establish a third order of government within Canadian federalism. This Accord would have radically altered the relationship between First Nation communities and the federal and provincial governments by readjusting the jurisdictions between governments. Unfortunately for all parties involved, the Accord failed in a nation-wide referendum, largely a result of its overall complexities. $^{11}$

Mulroney's government had temporarily averted the federal government's traditional policy of assimilation and concentrated more on transferring self-government powers to Indian governments. By way of constitutional talks, Mulroney recognized the need to devolve more spending powers to individual band governments. Appendix B reveals that between the years prior to 1987 constitutional discussions DIAND (Department of Indian Affairs and Northern Development) remained relatively consistent in maintaining control over Aboriginal programs. However, once constitutional discussions entered the government's agenda DIAND decreased its role in directing funds to specific programs and gradually transferred this function to Aboriginal governments.

To counteract the 1987 and 1990 Constitutional failings, the 1995 Inherent Right Policy was implemented to officially recognize Aboriginals' right to self-government. In addition, the Penner Report of 1983 was re-evaluated on the basis of its suggestions that the only other possible alternative to alleviate the poverty and social conditions existent in Aboriginal communities was through the devolution of powers to Aboriginal peoples. ${ }^{12}$ Consequently, DIAND finally acted on these recommendations, in combination with the proposals provided by the Royal Commission on Aboriginal Peoples (RCAP) Report, by applying the tools necessary for properly devolving powers to First Nations' governments under the First Nations Governance Act (FNGA).

The FNGA marks a new turn in the evolution of Aboriginal governance policy. Its sole directive is to expedite the process of autonomous First Nations' governments by supplying the tools for effective self-government. It was first introduced in the House of Commons on June 14, 2002 and re-instated October 9, 2002. Before a second reading could occur, the Chrétien government was replaced by Paul Martin's new administration in 2004 which included a new Minister of DIAND. The Act was not re-introduced. However, while this policy was on the

\footnotetext{
${ }^{11}$ Radha Jhappan, 'The Federal-Provincial Power-grid and Aboriginal Self-Government' in Rocher and Smith (ed). New Trends in Canadian Federalism, (Peterborough: Broadview Press, 1995), p. 173.

${ }^{12}$ Frances Abele, Katherine A. Graham and Allan Maslove, 'Negotiating Canada: Changes in Aboriginal Policy over the Last Thirty Years, in Leslie A. Pal (ed) How Ottawa Spends, (Toronto: Oxford University Press, 1999) p. 262.
} 
government agenda Robert Nault, the Minister of DIAND prior to the change in administration, claimed that the Indian Act was the most constraining element to the progression of Indian selfgovernment. Therefore he avowed to amend the Act and develop a system where Indians can "choose their leaders" and "develop clear rules regarding how they spend their money" 13 The principal plan of the FNGA was to encourage nation-building, institutional change, participation in the Canadian economy, and build a new fiscal relationship between the federal government, Aboriginal governments and Aboriginal communities. The policy would be implemented through the imposition of codes. These codes compel First Nations' governments to devise methods for leadership selection, administering band government, and instituting procedures for maintaining financial accountability. Band governments that fail to apply codes within a given two-year time frame will have their codes formulated by DIAND. Minister Robert Nault has continuously reiterated the fact that extensive consultation with Aboriginal communities had transpired before the Act was devised, and therefore he notes little reason for disrepute over its purpose and goals. ${ }^{14}$ However, significant discontent from Aboriginal communities inundated government officials shortly after its introduction.

Many Aboriginal peoples view the FNGA as little more than an extension of the Indian Act. Not only does it expand the authority of the Minister within Aboriginal affairs, but it also dictates to Aboriginal communities how they must assemble and conduct their governments' operations. The previous policy goal introduced by Mulroney during the Constitutional reform debates aimed at encouraging greater autonomy for Aboriginal governments and was now being rescinded. Instead the Ministry was returning to a policy of assimilation. The codes that Aboriginal governments were expected to implement resembled the institutional frameworks of Canadian governments as opposed to First Nations' traditional governing practices. Moreover, the increased involvement of the Minister reduces the power and legitimacy of Aboriginal governments. In addition to assenting to band government codes, the Minister supervises the conditions in which money is allocated, "how it will be accounted for, and what systems will be put in place at the band level to achieve this accountability". ${ }^{15}$

\footnotetext{
${ }^{13}$ Linda Ward, The First Nations Governance Act, (CBC News Online, June 14, 2002), accessed Mar. $14,2004$. www.cbc.ca/news/indepth/firstnations/indianact.html

${ }^{14}$ Robert Nault, Introduction to the House: First Nations Governance Act, (Hansard: House of Commons, On the Order: Government Orders) (1205)

${ }^{15}$ David Nicholson, “Indian Government in Federal Policy: An Insider's Views”, in Little Bear, Boldt and Long (ed) Pathways to Self-Determination: Canadian Indians and the Canadian State (Toronto: University of Toronto Press, 1984), p. 63.
} 
The FNGA signifies a shift in Aboriginal governance policy from the long-standing cultural assimilation that was evident with the establishment of residential schools, where Aboriginals were displaced from their families and raised in an environment that prohibited any practice of Indian culture, to a policy of institutional assimilation. Aboriginal systems of government are not only confronted with obstructions from the Indian Act, but they are now impeded by the FNGA since this recent policy is not intended to abolish the 129-year-old Act. The federal government is focused on eliminating the "administrative, political, legal and economic arrangements that set Indians apart from other Canadians". The goal of the federal ministry is to make Indian governments equivalent to municipalities. This would involve the phasing out of DIAND which is viewed as an obstacle to institutional assimilation, since its existence or any other ministry similar to it is not in accordance with the standard municipal relations with provincial governments. ${ }^{16}$ However, unlike Canadian municipalities, Indian governments are deprived of their autonomy especially in relation to the delivery of programs to their communities. ${ }^{17}$ This also demonstrates the shift to greater institutional assimilation.

In the period spanning Mulroney's and Chrétien's administrations, Aboriginal governance policy shifted noticeably. Appendix B validates that Aboriginal policy alternated from paternalism to devolution only to revert back to paternalism. Aboriginal governments encountered increased discretion over the direction of program funding until briefly after its peak in 1994 soon after the election of the Chrétien Liberal party. DIAND reasserted its paternalism in Aboriginal governing affairs, decreasing only slightly in 1996-1997 after the release of the Report by the Royal Commission on Aboriginal Peoples. Currently Aboriginal governance policy holds steady with Aboriginal governments possessing little discretion over the direction of programs while DIAND is again increasing its paternalistic role-most evident with the FNGA.

\section{II: Policy Actors}

By referring to the policy map in Appendix $\mathrm{C}$ it can be observed which actors are central to the policy process and the relation they have to each other. The evolution of the FNGA provides an adequate example of these actors' involvement in Aboriginal governance policy. Two of the most salient actors are the Prime Minister's Office and the Department of Indian Affairs and

\footnotetext{
${ }^{16}$ Currently there is debate over the establishment of a Ministry of Indian Relations to replace DIAND, which is more accepting to First Nations.

${ }^{17}$ Menno Boldt and J. Anthony Long, "Native Indian Self-Government: Instrument of Autonomy or Assimilation", in Long, Boldt and Little Bear (ed) Governments in Conflict: Provinces and Indian Nations in Canada, (Toronto: University of Toronto Press, 1988), p. 43-49.
} 
Northern Development (DIAND). Although the Prime Minister establishes the agenda for the Minister of DIAND, it is the Minister that coordinates the agenda of the PM. As was mentioned earlier the prominence of the Ministry often depends on the involvement of the PM in the department's agenda. Mulroney was rather submissive on the issue of Aboriginal governance policy while Chrétien, due to his past track record as Minister of DIAND, remained engaged in the agenda of this policy area. Hence, during Mulroney's tenure DIAND remained relatively subdued, but was more visible during Chrétien's administration.

Central agencies encounter two significant problems with the administration of Aboriginal governance policy that have a negative impact on the process. First, there are frequently numerous departments involved in different aspects of Aboriginal affairs, such as the Ministries of Justice, Labour, and Finance. The different interests of each department lead to conflicts that obstruct the successful implementation of policies and that contribute to the uncoordinated, ad hoc policies discussed earlier. This also increases the powers of the central agencies to referee the contradicting ideologies and interests. ${ }^{18}$ Second, consistent with all departments involved in some aspect of Aboriginal policy, few policy and program developers interact or have contact with Aboriginal peoples - their target population. The outcome is that policy-makers within these agencies and departments possess "little knowledge or understanding" of Aboriginal concerns. ${ }^{19}$

Similarly DIAND encounters a lack of understanding of Aboriginal concerns, but not to the same degree as other departments. Although some policy-makers may possess certain knowledge on Aboriginal issues, the direction of Aboriginal governance policy in this department can largely depend on the activist role of the Minister. ${ }^{20}$ Until DIAND was established in 1966, Ministers had remained relatively inactive in this portfolio or those portfolios that incorporated Indian Affairs. Once the Federal White Paper was introduced in 1969, the subject of Indian Affairs became a significant aspect on the government's agenda and increased the importance of the department and its Minister. Moreover, the concerns espoused by the rising Aboriginal political organizations, as a response to the White Paper, required greater

\footnotetext{
${ }^{18}$ Sally Weaver, 'Federal Difficulties with Aboriginal Rights Demands', in Boldt, Long and Bear (ed) The Quest for Justice, (Toronto: University of Toronto Press, 1985) p. 145 \& 141.

${ }^{19}$ David Nicholson, "Indian Government in Federal Policy: An Insider's Views", in Little Bear, Boldt and Long (ed) Pathways to Self-Determination: Canadian Indians and the Canadian State (Toronto: University of Toronto Press, 1984), p. 61.

${ }^{20}$ Frances Abele, Katherine A. Graham and Allan Maslove, 'Negotiating Canada: Changes in Aboriginal Policy over the Last Thirty Years, in Leslie A. Pal (ed) How Ottawa Spends, (Toronto: Oxford University Press, 1999) p. 285.
} 
attention from the government and also attributed to the increasingly activist role of the Minister of DIAND. The origin of the FNGA is the result of Minister Robert Nault's adamant pursuit in fulfilling the recommendations of the Royal Commission on Aboriginal Peoples.

The Royal Commission on Aboriginal Peoples (RCAP) was instituted by the federal government in August 1991 for two primary reasons: 1) to improve the relationship between the federal government and Aboriginals - a goal largely motivated by the adverse effects of the Oka Crisis, and 2) to provide an updated and extended version of the 1966 Hawthorn Report which advocated a "need for cultural revival...as a precursor to social rehabilitation and economic development". ${ }^{21}$ The Commission discovered, through extensive consultations in 1992, the necessity for Aboriginal peoples to re-instate independent band governments and restructure the relationship between Aboriginals and non-Aboriginals. ${ }^{22}$ In 1996 the Commission released its long-overdue report to the House of Commons. Its key findings pertaining to Aboriginal selfgovernment include: renewing the partnership between the federal government and Aboriginals; strengthening Aboriginal governance by means of establishing a third order of government and dividing jurisdictions; developing a new fiscal relationship by reforming the method of transfer payments and financial accountability; federal recognition and execution of Aboriginal Treaties - new and old; and supporting strong communities, people and economics through the development of band autonomy from federal government initiatives and greater band legitimacy and accountability to communities. ${ }^{23}$ Numerous interest associations were contacted for feedback on this report; however RCAP's negligence in consulting any of the prominent Aboriginal women's organizations including the Native Women's Association of Canada (NWAC) ignited a demand for greater inclusion in government policy.

Since the late 1960s considerable attention has been dedicated to a variety of Aboriginal political organizations demanding increased involvement in discussions affecting their welfare. Combined with the introduction of the controversial White Paper in 1969, the initiation of federally funding for Aboriginal political organizations produced a significant increase in the numbers and exposure of these organizations. Moreover, the enfranchisement of Aboriginal

\footnotetext{
${ }^{21}$ Ibid; p. 276, 257.

22 J Anthony Long \& Katherine Beaty Chiste, 'Aboriginal Policy and Politics: The Charlottetown Accord and Beyond', in Watts and Brown (ed) Canada: The State of the Federation 1993, (Kingston: Institute of Intergovernmental Relations, 1993), p. 170-1.

${ }^{23}$ Royal Commission on Aboriginal Peoples, Restructuring the Relationship, (Indian \& Northern Affairs Canada, 1996), www.ainc-inac.gc.ca/ch/rcap/rpt/rel_e.html accessed January 26, 2004. p. 1-9.
} 
peoples almost a decade earlier rendered them a highly influential voting population. ${ }^{24}$ Mobilization of Aboriginal peoples was no longer being impeded and they could now defend their interests effectively in the Canadian political and judicial arena.

Currently there are five major national Aboriginal organizations: the Assembly of First Nations (AFN) established in 1982, the Congress of Aboriginal Peoples (CAP) formed in 1970, the Inuit Tapiriiksat Kanatami (ITC) created in 1975-6, the Métis National Council (MNC) founded in 1982, and the Native Women's Association of Canada (NWAC) established in 1974. This paper will concentrate on the role of the most influential of Aboriginal political organization - the Assembly of First Nations. The predecessor of the AFN was the National Indian Council followed by the National Indian Brotherhood. Each of these organizations failed due to consistent problems with fragmentation caused mainly by reluctant provincial and territorial leaders to relinquish their powers to a national body. The AFN increased the grassroots links and instilled greater power with the newly established positions of the national chief and forty-eight other executive members more formally known as the Confederacy of Nations. The conception of the AFN did not resolve all the initial problems existent in its predecessors. The lingering problem remained the AFN's difficulty in maintaining a national consensus between Indian bands across the country-best demonstrated by the failure of the Charlottetown Accord. ${ }^{25}$ However, the introduction of the FNGA has successfully mobilized the AFN into a united front with the majority of Indian bands fixed on defeating this Bill. The AFN has become the most utilized source of consultation for the federal government, which inevitably assisted the Joint Ministerial Advisory Committee (JMAC) in devising the framework for the FNGA.

On November 20, 2001 the JMAC held its first session and consisted of expert bureaucrats, both Aboriginal and non-Aboriginal, knowledgeable on issues of Aboriginal governance. Its directive was influenced in part by RCAP's recommendations and was instructed by the Minister of DIAND to establish a means in assisting Aboriginal band governments in becoming more accountable to their communities. Regrettably, the JMAC's advice delivered in its final report on March 2, 2002 was not accurately implemented in the completed Act. The JMAC optimized for leadership selection tools, accountability and financial management measures, but also emphasized the necessity for band governments to be more institutionally

\footnotetext{
${ }^{24}$ Linda Ward, The First Nations Governance Act, (CBC News Online, June 14, 2002), accessed Mar. 14, 2004. www.cbc.ca/news/indepth/firstnations/indianact.html

${ }^{25}$ Joe Sawchuck, The Dynamics of Native Politics: The Alberta Métis Experience, (Saskatoon: Purich Publishing, 1998), p. 32-34.
} 
independent. ${ }^{26}$ Ultimately Robert Nault manipulated the report by ignoring the latter suggestion and instead increased the authority of the government in the establishment of the former recommendations. The high degree of Ministerial involvement in the selection of band leaders and enforcing band governments' accountability diminishes the role of community members in these activities. In essence, the FNGA contradicts the department's long-term policy goals by only offering band governments fabricated, self-defeating governing tools in contrast to promoting greater control over their own band governments. These concerns were soon noted once the Act was introduced in the House and the government referred it to the Standing Committee on Aboriginal Affairs before the second reading.

Established on January 27, 2003, the Standing Committee would enable interested parties to voice their opinions on the FNGA and continue the deliberation between the federal government and Aboriginals. An additional purpose of the Committee was to provide an assessment on the legality and feasibility of the Act. The expert advice of the Auditor General of Canada, Sheila Fraser, provided statements to announce the impracticalities of the Act-the most outstanding was the notion that the Act failed to consider the size of different Aboriginal communities and therefore it is unreasonable to implement stringent criteria on smaller communities without the power or resources to do so. Furthermore, she notes that it is unreasonable to demand extensive reporting practices on smaller communities. ${ }^{27}$ Overall, the Standing Committee's final evaluation urges the federal government to improve the accountability relationship between Aboriginal governments and their citizens by removing the wardship-type influence (control and compliance) exhibited in the federal government attitude. ${ }^{28}$ Robert Nault's relentless determination to implement the FNGA, regardless of the requested changes by other government actors and Aboriginal organizations, was finally put to an end with his removal from office during the Martin government.

Aboriginal governance policy is influenced by minor, but nevertheless quite relevant, policy actors. Opposition members in the House are very cautious with the introduction of Aboriginal governance policy partly due to its contentious nature. Opposition leaders have the

\footnotetext{
${ }^{26}$ Joint Ministerial Advisory Committee, Recommendations and Legislative Options to the Honorable Robert Nault, P.C., M.P., Minister of Indian Affairs and Northern Development, FINAL REPORT, March 8, 2002. www.fnggpn.gc.ca/JMACFR M802 e.html accessed December 19, 2003.

${ }^{27}$ Sheila Fraser, Opening Statement to the Standing Committee on Aboriginal Affairs, Northern Development and Natural Resources, January 28, 2003. www.oag-bvg.gc.ca/domino/other.nsf/html/03aa01_e.html accessed October 16, 2003.

${ }^{28}$ Standing Committee on Aboriginal Affairs, Effective First Nation Governance, (Slide Show Presentation, February 21/26, 2002) www.fng-gpn.gc.ca/pres/fngfeb28/sld001.html accessed November 10, 2003.
} 
ability to note the concerns of Aboriginals in the House that government leaders neglect to address thereby offering Aboriginals another alternative for redress. Joe Clark, Conservative MP, raised the issue that the Act was significantly flawed since it required numerous amendments, ${ }^{29}$ while the New Democratic Party leader Jack Layton pressured Paul Martin, a leading Liberal MP at the time, to vote against the Bill. ${ }^{30}$ Layton's request was fulfilled when the Bill was not reintroduced under Martin's government.

Aboriginals also have an advantage with the Courts. In most instances court rulings favour Aboriginals and with that, "the scope of their governance capacities expands as the courts clarify treaty rights". ${ }^{31}$ In regards to the FNGA, one First Nation group in particular, the Federation of Saskatchewan Indian Nations, has challenged the Act with great success. The government's attempt to have the Federation's claim dismissed has been rejected on two occasions. ${ }^{32}$ The provinces share the federal government's apprehension of the judiciary's involvement in Aboriginal affairs. The provinces' primary concern is the potential for overlap in provincial jurisdiction ensuing in the division of resources between provinces and Aboriginal governments. This is already evident with economic and energy meetings being conducted involving the two orders of government, ${ }^{33}$ and the tendency for the provinces to ignore Aboriginal interests when conceding resource licences to third parties. ${ }^{34}$ At the same time, the provinces welcome Aboriginal self-government because it would reduce the off-loading of federal responsibilities on to the provinces in the area of Aboriginal affairs. Conflicts between the federal and provincial governments would be expected to subside when greater responsibility is transferred to band governments. ${ }^{35}$

International actors such as Amnesty International and the United Nations (UN) are strong allies with Aboriginals when confronting the provincial and federal governments. Part of

\footnotetext{
${ }^{29}$ Hon. Joe Clark, Points of Order: First Nations Governance Act, $\left(37^{\text {th }}\right.$ Parliament, $2^{\text {nd }}$ Session, June 3,2003$)$, (1550) www.parl.gc.ca/37/2/parlbus/chambus/house/debates/110 2003-06-03/han110 1550-E.htm\#SOBQaccessed November 12, 2003.

${ }^{30}$ Jorge Barrera, 'Layton Challenges Martin to Vote Against Governance Act', Daily Miner \& News, May 16, 2003, pg. A2.

31 J. Kaufman and F. Roberge, Aboriginal Governance in the Canadian Federal State 2015, (Kingston: Institute of Intergovernmental Relations, Working Paper 2003), p. 7.

32 'Saskatchewan Aboriginal group proceeding with court challenge to Indian Act changes', Canadian Press Newswire, September 1, 2003.

${ }^{33}$ Roy Romanow, 'Aboriginal Rights in the Constitutional Process', in Boldt, Long and Bear (ed) The Quest for Justice, (Toronto: University of Toronto Press, 1985) p. 76.

${ }^{34}$ Radha Jhappan, 'The Federal-Provincial Power-grid and Aboriginal Self-Government' in Rocher and Smith (ed). New Trends in Canadian Federalism, (Peterborough: Broadview Press, 1995), p. 179.

${ }^{35}$ Frances Abele and Michael J. Prince, 'Aboriginal Governance and Canadian Federalism: A To-Do List for Canada', in Rocher \& Smith (ed) New Trends in Canadian Federalism (Peterborough: Broadview Press, 2003), p. 143
} 
the UN's agenda is to "decolonize" by granting self-determination to peoples that were once subject to colonization. The UN has identified self-determination as a right, which has put significant pressure on the federal government to change its approach towards this issue. ${ }^{36}$ An explanation as to why the federal government does not alter its agenda of interference will be discussed in a moment, but first it can be observed that the prominence of these policy actors has changed since the 1990s. Aboriginal political organizations have increased their influence as the authority of the Minister of DIAND has alternated. Both international organizations and Parliamentarians are fully aware of the growing support from the public through public opinion polls on granting increased recognition of Aboriginal entitlements, including self-governing authority. ${ }^{37}$ Increasingly all Aboriginals, rather than just select groups, have been encouraged to become more involved in government discussions relevant to their welfare. ${ }^{38}$ Under the new Martin regime, it is very likely that DIAND will gradually lose its importance again while Aboriginals acquire greater control over their own affairs.

\section{III: Problems Afflicting Aboriginal Governance Policy}

There are a variety of reasons that Aboriginal governance policy has remained relatively unsuccessful. The two most apparent reasons include: 1) the federal government choosing to maintain a practice of path dependency, and 2) First Nations and the Canadian governments possessing contrasting political philosophies.

\section{Path Dependency Theory}

The federal government began its long track record of paternalism with the institution of the Indian Act, and as we have observed this mind-set is evident in almost every policy following up to today. It is fitting to classify this behaviour as path dependency in which the government "has started down a track [and] the costs of reversal are very high". Institutional arrangements obstruct an easy reversal of this behaviour making the costs of exit rise, hence reinforcing the process. ${ }^{39}$ In the case of Aboriginal self-government, the Constitution was what originally

\footnotetext{
${ }^{36}$ James Youngblood Henderson, 'Empowering Treaty Federalism', (Saskatchewan Law Review vol. 58, 1994), p. 281.

${ }^{37}$ Dan Russell, A People 'sDream: Aboriginal Self-Government in Canada, (Vancouver: UBC Press, 2000$)$, ,p.199.

${ }^{38}$ Royal Commission on Aboriginal Peoples, Soliloquy and Dialogue and Dialogue: Overview of Major Trends in Public Policy Relating to Aboriginal Peoples, (Ottawa: Minister of Public Works and Government Services Canada, 1996), 181.

${ }^{39}$ Paul Pierson, 'Increasing Returns, Path Dependence and the Study of Politics', (American Political Science Review, vol. 94, no. 2, June 2000), p. 252.
} 
constrained this policy. Now with the recognition of Aboriginals' inherent right to selfgovernment in the 1995 Inherent Right Policy, this constraint has been eliminated. Nevertheless, the limitation of the division of powers poses a new restriction that Aboriginals must overcome in their quest for independence. Federal and provincial governments are unsupportive of constitutionally dividing jurisdictions any further with a third order of government. The Canadian governments' path dependency can be characterized by three elements - inflexibility, nonergodicity, and potential path inefficiency.

'Inflexibility' implies that "the farther into the process [one is], the harder it becomes to shift from one path to another". ${ }^{40}$ In reference to the federal government, the entrenchment of assimilation within government policy over the past century has made it difficult to even distinguish what policies can be considered assimilationist. Therefore, without properly defining it or acknowledging it in policies, the government will continue to deny Indians self-government. 'Nonergodicity' is where "accidental events early in a sequence do not cancel out...small events are remembered". ${ }^{41}$ For example, the erosion of Aboriginal political culture enforced by the federal government (imprisonment of Aboriginal chiefs for practicing traditional methods of government in the early $20^{\text {th }}$ century) is remembered by Aboriginals especially when the memory is refreshed with the control the Minister has over leadership selection. Finally, 'potential path inefficiency' demonstrates that the long-standing practice eventually becomes permanent and would incur greater disadvantages for the target group than it would if it implemented an entirely new alternative. ${ }^{42}$ In essence, the sustained paternalism is more detrimental for Aboriginals than would be the cost of conceding greater autonomy to band governments. In regards to Aboriginal governance policy, history is crucial. Randall Hansen adds to the definition by stipulating that "path dependency is established only when it can be shown that policy change was considered and rejected for reasons that cannot be explained". ${ }^{43}$ Reducing the authority and control of the Minister of Aboriginal Affairs was frequently recommended, yet the government refused to make the appropriate modifications to the FNGA that would diminish the Minster's role.

The costs associated with the accommodation of Indian demands are considered high by the Canadian governments. The concept of Aboriginal nationhood challenges Canadian

\footnotetext{
40 Ibid; 253

${ }^{41}$ Paul Pierson, 'Increasing Returns, Path Dependence and the Study of Politics', (American Political Science Review, vol. 94, no. 2, June 2000), p. 253.

42 Ibid; 253.

${ }^{43}$ Randall Hansen, 'Globalization, Embedded Realism, and Path Dependence', (Comparative Political Studies, vol. 35, no. 3, Apr. 2002), p. 271.
} 
sovereignty, and "territorial integrity". According to the federal government's philosophy, Aboriginal self-government will only stimulate other potential problems. The easiest solution is to uphold the course of "protection, civilization, and assimilation". 44

\section{Contrasting Political Thought}

The lack of understanding Aboriginals and the Canadian governments have towards each others' political culture and ideologies is one of the most significant problems impeding the success of Aboriginal governance policy. This lack of understanding has resulted in competing visions over the direction of policy goals. However, since Aboriginals have been exposed to Canadian culture and political thought in large doses they tend to have a better grasp of Canadian culture than is true of Canadian governments with respect to Aboriginal culture. First Nations political culture is premised on the context of collectivities and an attachment to nature. Appendix D compares the opposing views on government, economics, property and basic values. It indicates that many of the Aboriginal ideologies are incompatible with Western practices. Consequently, this results in challenges to the Canadian governments. For instance, in order for Aboriginal communities to become developed and self-sustaining it is necessary for them to adopt Western thought including methods of governing. There seems to be a narrow outlook among Canadian governments that Western thought cannot be modified to accommodate Aboriginal political culture. But it has been confirmed that Aboriginal culture can be reformed to incorporate some aspects of Western culture at the same time as it is devoted to preserving its culture. The core of its identity is in the commitment to keep members and the community together over time. ${ }^{45}$ They are fighting a constant battle with the governments - while Aboriginals encourage members to remain in the community, governments persuade First Nations peoples to leave reserves and find employment in Canadian society. First Nations leaders believe that since governments have not been exposed to external threats on their sovereignty and identity in recent decades, they do not understand Aboriginal peoples' position and therefore have the "natural tendency" to place First Nations' governing rights on the side. ${ }^{46}$

\footnotetext{
${ }^{44}$ Kiera Ladner and Michael Orsini, 'The Persistence of Paradigm Paralysis: The First Nations Governance Act as the Continuation of Colonial Policy' in M. Murphy (ed), Canada: State of the Federation, 2004. (unpublished) p. 11.

${ }^{45}$ Tim Schouls, Shifting Boundaries: Aboriginal Identity, Pluralist Theory, and the Politics of Self-Government, (Vancouver: UBC Press, 2003), p. 172.

${ }^{46}$ Roy Romanow, 'Aboriginal Rights in the Constitutional Process', in Boldt, Long and Bear (ed) The Quest for Justice, (Toronto: University of Toronto Press, 1985), p. 81.
} 
There are many other reasons behind the governments' limited understanding of First Nations demands for greater autonomy - two of which depend on the government's ideology, while another stems from the personalities of the leading politicians. Liberal democracy prevails in the basic ideology of government policies in Western society. Strongly accentuated during Trudeau's government, liberal-democratic theory promotes individuality, equality, and freedom from discrimination. The notion of supplying programs on the basis of special status, collective rights and cultural uniqueness is contradictory with the government's commitment to liberal democracy. Thus, to privilege First Nations with special rights to self-government becomes problematic. ${ }^{47}$ Moreover, Canadian policy-makers and politicians also misunderstand the concept of communitarianism, sharing of property and uniformity internal in First Nations' cultures. Many still tend to believe Indians' struggle to protect their traditional culture and government is futile since they have already absorbed so much Western culture over the centuries that their own culture has become diluted. ${ }^{48}$ The Indian Act is a perfect example of how Aboriginal political culture has absorbed Western political culture. It will not matter how much Aboriginals attempt to rectify their traditional forms of government, because the Act is engrained to such an extent in current Aboriginal governing systems that the precise operation of their original governments has been forgotten. This is considered a misconception by Aboriginal peoples. It is often a reality for smaller band governments that do not have the appropriate resources to make a partial transition back to their original governments, but for larger Indian governments - with the proper resources - the conversion is much more possible.

Increasingly, since the 1970s, government administrators or policy-makers that have the understanding and knowledge of Aboriginal political culture are declining in numbers. Individual ministers lack the skills to respond to Aboriginal demands for self-government and without the appropriate public-servant activists who can promote, facilitate and "translate [First Nations'] demands into policy forms acceptable to cabinet", the government will remain ignorant of the needs of Aboriginals. ${ }^{49}$

Even with public-servant activists present in government their endeavors may be in vain. The government's overall ideology and progress on Aboriginal governance policy is heavily dependent on the personality and ideals of the government leader. During Chrétien's tenure as

\footnotetext{
${ }^{47}$ Sally Weaver, 'Federal Difficulties with Aboriginal Rights Demands', in Boldt, Long and Bear (ed) The Quest for Justice, (Toronto: University of Toronto Press, 1985) p. 142.

${ }^{48}$ Ibid; 146.

${ }^{49}$ Sally Weaver, 'Federal Difficulties with Aboriginal Rights Demands', in Boldt, Long and Bear (ed) The Quest for Justice, (Toronto: University of Toronto Press, 1985) p. 143.
} 
Minister of Aboriginal Affairs under Trudeau's administration, he was enthusiastic with the governments' agenda to dismantle the Indian Act, which was evident in his construction of the 1969 White Paper. His involvement in the Ministry was not abated throughout his tenure as Prime Minister. Chrétien's strong support over the FNGA in the House is evidence of this, and it raises questions on whether he truly instigated the policy. ${ }^{50}$ Nevertheless, the new Prime Minister, Paul Martin, will determine the course of the FNGA. Martin approaches Aboriginal governance issues much more passively and with greater caution than his predecessor. This may be in part due to his lack in experience and knowledge on the issue. According to Martin, he is unsupportive of the Bill and promises that the Bill will not be re-introduced in the House. ${ }^{51}$ As of today, he continues to fulfill that promise; however, he has moved one step further by replacing the aggressive Robert Nault with more passive Ministers of DIAND, such as Andy Mitchell and Andy Scott. The direction of Aboriginal governance policy also reflects the perception of Aboriginal leaders. Matthew Coon Come, previous Chief of the Assembly of First Nations, is a strong opponent of the FNGA and refused to make any concessions to have the Bill passed in the Legislature. However, the current Chief, Phil Fontaine, raised anxious questions from some Aboriginal communities because he had such a strong stance on negotiating the Bill and was not outright hostile to its survival. ${ }^{52}$ The cultural values and modes of thinking have a noticeable impact on the differences in policy goals for both First Nations and Canadian governments.

The prime policy objective for First Nations leaders is to extinguish band councils as an “administrative arm" for DIAND, and instead accentuate their self-governing capacities through greater law-making and law-enforcing powers. They reject the institution of governing methods that resemble existing Canadian systems of government, especially the imposed municipal system. First Nations leaders are seeking to define exactly what form of self-government is necessary to suit the needs of First Nations peoples thereby providing a clear vision and legitimacy for community members and the Canadian governments to appreciate. ${ }^{53}$ Aboriginal peoples share common interests that are projected in their goals - to preserve the "shared historical memories, elements of common culture, ties to specific territory, and a sense of solidarity"-all of which cannot be achieved without significantly enhancing communal power

\footnotetext{
${ }^{50}$ Right Hon. Jean Chrétien, Oral Question Period no. 095: Aboriginal Affairs, $\left(37^{\text {th }}\right.$ Parliament, $2^{\text {nd }}$ Session, May 5 , 2003), (1425) www.parl.gc.ca/37/2/parlbus/chambus/house/debates/095 2003-05-05/ques095-E.htm\#SOB-527105, accessed November 12, 2003.

${ }^{51}$ Kady O’Malley, 'First Nations Governance Act is dead: Chief Coon Come...', (Hill Times, July 7, 2003).

52 Jorge Barrera, 'Governance Act could pass in fall', (Daily Miner \& News, June 17, 2003), p. A1.

53 J. Anthony Long and Menno Boldt, Governments in Conflicts: Provinces and Indian Nations in Canada, (Toronto: University of Toronto Press, 1988), p. 51 \& 53.
} 
through self-government and removing external domination and constraints. ${ }^{54}$ In relation to this, Indian self-government can enforce limits on extensive commercialization and advertisements that endanger their culture. Federal government policy encourages commercial and industrial development in Aboriginal communities; however, the government fails to realize how this can have harmful implications on First Nations peoples. This is not to suggest that Aboriginals oppose economic development; rather, they are prudent with the choice of industry that will welcome in their communities. ${ }^{55}$ The disparity between Aboriginals and the federal government in the area of economic development is but one example of contrasting policy goals. Another example is the differing views over the treaty process noted in Appendix E. First Nations' longstanding concept of treaties involves an enduring relationship between the two parties involved that requires periodic renewals. Canadian governments interpret treaties as a contract that can be circumvented by constructing a newly reformed treaty. Although the federal government's intentions may be constructive, the underlying results of their actions in Aboriginal governing affairs are frequently not in the interests of First Nations.

The federal government's policy goals recurrently counter the objectives of First Nations, especially in recent years. Gradually, since the mid-1990s, the federal government has shifted from an agenda of social-justice to one of economic concern. ${ }^{56}$ Less attention and funding is allotted to First Nations issues due to economic restraint and their concerns are dealt with in the most efficient manner for the federal government (but certainly not the best manner). This is evident in Appendix B. Four other policy paradigms emerge in federal Aboriginal governance policies that are noted by the Royal Commission on Aboriginal Peoples. First, the federal government maintains the subtle yet distinct assimilationist position treating Aboriginal societies similar to those of regular Canadian citizens. Second, the 'citizens plus' perspective entails that the direct descendents of treaty signatories possess special rights as a result of their status; in addition to ascertaining the rights of regular citizens. Third, the rights-based approach entitles all Aboriginals in Canada (including non-status, Inuit and Métis) to universal rights as an expression of their "aboriginality". Fourth, is the sovereigntist paradigm in which First Nations are viewed as separate nations that require diplomatic relations between Aboriginals and non-Aboriginals.

\footnotetext{
${ }^{54}$ Tim Schouls, Shifting Boundaries: Aboriginal Identity, Pluralist Theory, and the Politics of Self-Government, (Vancouver: UBC Press, 2003), p. 177 \& 38.

55 J. Kaufman and F. Roberge, Aboriginal Governance in the Canadian Federal State 2015, (Kingston: Institute of Intergovernmental Relations, Working Paper 2003), p. 32.

${ }^{56}$ Sally Weaver, 'Federal Difficulties with Aboriginal Rights Demands', in Boldt, Long and Bear (ed) The Quest for Justice, (Toronto: University of Toronto Press, 1985) p. 143.
} 
RCAP identifies that these paradigms, which are manifest in all federal government Aboriginal governance policy, are incoherent and contradicting. ${ }^{57}$ These paradigms are essentially the policy guidelines the federal department has adhered to for decades and lack the creativity to devise new policy categories to deal with Aboriginal governing affairs. Employing two or more of these paradigms within the same policy (such as the assimilationist and sovereigntist paradigm) create inconsistencies that, among other things, cause inefficiency and the continued exclusion of Aboriginal peoples in the development of this policy area.

A further demonstration of the federal government's differing priorities is its reliance on the 1995 Inherent Right policy. This policy concentrates to a large extent on municipal and provincial responsibilities as the foundation of self-government and denies First Nations governments any federal responsibilities that pertain to their welfare (note Appendix A). ${ }^{58}$ Many Indian leaders fear the federal government's association of Indian self-government with municipal government, and these leaders refuse to accept imitations of Canadian institutions as their form of government. ${ }^{59}$ It is quite clear that the political culture of First Nations leaders and Canadian policy-makers strongly affects the policy goals of each party. Thus, to rectify these disparities and promote understanding it is imperative that First Nations peoples influence the policy direction of programs concerning their interests.

\section{IV: Improving the Role of First Nations in Policy Making}

Three promising solutions for successful Aboriginal governance policy are better consultation, greater representation for First Nations peoples, and, most importantly, treaty federalism.

\section{Consultation}

Presently the consultation process between First Nations peoples and the Canadian government is seriously flawed. It is well documented that proper consultation with Aboriginals is necessary to make adequate policy, yet little has been done to improve the process. The same nuances that

\footnotetext{
${ }^{57}$ Royal Commission on Aboriginal Peoples, Soliloquy and Dialogue and Dialogue: Overview of Major Trends in Public Policy Relating to Aboriginal Peoples, (Ottawa: Minister of Public Works and Government Services Canada, 1996), p. 47-48.

${ }^{58}$ Frances Abele, Katherine A. Graham and Allan Maslove, 'Negotiating Canada: Changes in Aboriginal Policy over the Last Thirty Years, in Leslie A. Pal (ed) How Ottawa Spends, (Toronto: Oxford University Press, 1999) p. 281.

${ }^{59}$ Frank Cassidy and Robert L. Bish, Indian Government: Its Meaning in Practice, (Halifax: The Institute for Research on Public Policy, 1989), p. 24.
} 
existed twenty years ago continue today. In a DIAND backgrounder report dated June 1984 it states:

In the fall of 1982 the Department of Indian Affairs and Northern Development put forward discussion papers which outlined a devolutionary approach to self-government, based on the existing system of Band Governments. This approach was criticized partly for its content and thrust, but also for the perceived lack of formal consultation with Indian people (emphasis added). ${ }^{60}$

A substantial part of the problem with consultation is that the government has failed to devise an appropriate mechanism for consultations. A method of joint decision-making between Aboriginals and non-Aboriginals must be conducted. Few policy-makers, as has been observed earlier, do not possess the field experience to understand their target population, making it difficult to design programs that properly address Aboriginals' needs. Concurrently, it is insulting to regard First Nations as a target population who are unable to contribute meaningful insights in this policy area. ${ }^{61}$ It denotes an identity of being objects rather than subjects in the discussion of public policy. ${ }^{62}$ Involving First Nations peoples in the most integral aspect of the policy process - problem definition or identifying the policy goals - can help alleviate this problem. Often policy makers in the federal government evade input from Aboriginals when formulating potentially new policy. ${ }^{63}$ Hindering consultation at the first stage of the policy process allows government officials to push their agenda on Aboriginal leaders and simply reserve the following stages for consultation. Meanwhile, First Nation leaders lack any opportunity to shape the policy from the beginning, help establish government priorities or make significant changes without reversing the policy. Consultation between stages, but not at the start, is considered a strategic method for legitimizing the policy process.

The FNGA encountered similar predicaments. Very little consultation occurred prior to the introduction of the Bill, except in regards to the discussions that ensued during the JMAC. However, the design of the Act failed to involve First Nations leaders or their political organizations directly. Instead, government officials approached organizations representing

\footnotetext{
${ }^{60}$ Ministry of Indian and Northern Affairs and Northern Development Canada, Historical Context, Backgrounder/Documentation, June 1984.

${ }^{61}$ Kiera Ladner and Michael Orsini, 'The Persistence of Paradigm Paralysis: The First Nations Governance Act as the Continuation of Colonial Policy' in M. Murphy (ed), Canada: State of the Federation, 2004. (unpublished) p. 15.

${ }^{62}$ Royal Commission on Aboriginal Peoples, Soliloquy and Dialogue and Dialogue: Overview of Major Trends in Public Policy Relating to Aboriginal Peoples, (Ottawa: Minister of Public Works and Government Services Canada, 1996), p. 48-49.

${ }^{63}$ David Nicholson, "Indian Government in Federal Policy: An Insider's Views”, in Little Bear, Boldt and Long (ed) Pathways to Self-Determination: Canadian Indians and the Canadian State (Toronto: University of Toronto Press, 1984), p. 64.
} 
groups, such as the Métis and non-status peoples, that have no vested interest in the changes this Act would have on the Indian Act. ${ }^{64}$ The government boasted about the numerous methods for consultation-community meetings, information sessions, discussion groups, toll-free numbers, and the website (e-mail). ${ }^{65}$ What the government tended to ignore was that many of the community meetings were short of attendance. Also, out of more than 600 First Nations communities, only 200 were consulted. Overall, only 3\% of First Nations citizens requesting to participate in the consultations were permitted - a number that Robert Nault believes was an accomplishment. ${ }^{66}$ Fortunately, progress on a general scale has been positive in the direction of increased consultation. Intergovernmental meetings involving the direct participation of Aboriginal leaders are becoming more prevalent. Approximately three years ago, there were virtually no such conferences, and now several take place annually. Further advancement would be made with Aboriginal inclusion in the Annual Premiers' Conferences. ${ }^{67}$ Improving the methods of consultation is only part of the problem. Remedying the lack of representation among Aboriginals in the federal government and the policy process will enhance Aboriginal governance policy considerably.

\section{Representation}

Some scholars argue that increased Aboriginal political representation within Canadian institutions is highly beneficial for First Nations to influence the policy process. Others disagree. Until 1960 Aboriginals were excluded from enfranchisement resulting in years of ignorance of Canadian political, social, and legal institutions. Hence, Aboriginal political organizations developed to offset the insufficient number of Aboriginal members in the federal and provincial legislatures. At present, there remains little influence from sitting Aboriginal members on the issues of Aboriginal governance policy. It has been suggested that a specific number of seats should be designated for Aboriginal members, which has been attempted in countries like New

\footnotetext{
${ }^{64}$ Kiera Ladner and Michael Orsini, 'The Persistence of Paradigm Paralysis: The First Nations Governance Act as the Continuation of Colonial Policy' in M. Murphy (ed), Canada: State of the Federation, 2004. (unpublished) p. 6.

${ }^{65}$ Ministry of Indian Affairs and Northern Development, About Governance: What We Heard, www.fnggpn.gc.ca/AB e.html, accessed Oct. 16, 2003.

${ }^{66}$ Hansard. House of Commons Debate: Aboriginal Affairs. $37^{\text {th }}$ Parliament, $1^{\text {st }}$ session, June 14, 2002. www.parl.gc.ca/37/1/parlbus/chambus/house/debates/206_2002-06-14/han206_1135-E.htm\#SOB-287675 accessed Nov. 12, 2003. (1140)

${ }^{67}$ Frances Abele and Michael J. Prince, 'Aboriginal Governance and Canadian Federalism: A To-Do List for Canada', in Rocher \& Smith (ed) New Trends in Canadian Federalism (Peterborough: Broadview Press, 2003), p. 145 .
} 
Zealand ${ }^{68}$ Increasing the number of reserved seats will also provide more opportunities for the government to establish special committees on Aboriginal governance issues that are managed by Aboriginals. So far the only progress the government has made in this direction is anointing MP/MPPs who have constituencies heavily populated by Aboriginal peoples. Frequently, but not always, this small group has ample knowledge on Aboriginal issues. ${ }^{69}$

It is argued that the lack in representation of Aboriginals in Canadian legislatures is not solely attributed to their ignorance of the system or to their failure in being elected. Many Aboriginals maintain the long-standing view that any participation in the Canadian political system implies consent to political assimilation. Canadians and policy-makers alike may perceive that sufficient representation of Aboriginals in the Canadian government diminishes the need for Aboriginal self-government, lessening the pressure felt from First Nations political organizations. Moreover, it is not guaranteed that once Aboriginals who are elected to office will have the capacity to influence policy due, in large part, to party discipline. ${ }^{70}$ Since representation is neither effective nor beneficial for improving First Nations in policy-making the only possible alternative is an entirely different approach.

\section{Treaty Federalism}

Canada has not yet detached itself from being identified as a colonial state. The government consistently denies a significant and growing portion of its population from governing itselfevident in the lack of representation in Canadian institutions. Regardless of court decisions recognizing Aboriginal and treaty rights as constitutionally supreme law under sections 25 and 35 of the Constitution Act 1982, politicians and policy-makers fail to recognize these resolutions. In Canada, the fact remains - treaty and Aboriginal rights are still viewed as inferior to constitutional rights. ${ }^{71}$ Moreover, they continue to ignore the basic principle of the rule of law: "that all peoples, despite race or ethnicity, are to be secure in what the Crown has recognized as

\footnotetext{
${ }^{68}$ Joe Sawchuck, The Dynamics of Native Politics: The Alberta Métis Experience, (Saskatoon: Purich Publishing, 1998), p. 70.

${ }^{69}$ Paul Tennant, 'Aboriginal Rights and the Penner Report on Indian Self-Government', in Boldt, Long and Bear (ed) The Quest for Justice, (Toronto: University of Toronto Press, 1985) p. 327-328.

${ }^{70}$ Menno Boldt and J. Anthony Long, "Native Indian Self-Government: Instrument of Autonomy or Assimilation", in Long, Boldt and Little Bear (ed) Governments in Conflict: Provinces and Indian Nations in Canada, (Toronto: University of Toronto Press, 1988), p. 50.

${ }^{71}$ James Youngblood Henderson, 'Empowering Treaty Federalism', (Saskatchewan Law Review vol. 58, 1994), p. 286.
} 
their liberties and entitlements". ${ }^{72}$ First Nations by no means have had their sovereign status legally removed at any time throughout pre or post Confederation. ${ }^{73}$

According to James Youngblood Henderson, the most appropriate solution for rectifying this negative persona is to enforce treaty obligations. These treaty obligations were first negotiated for the purpose of sharing Indian land and resources with settlers. In addition, they defined the nature of the Aboriginal and British government's relationship and specified that by sovereign right the Crown or agents of the Crown have the authority to deal with some administrative matters while First Nations "retain legal and governmental authority". 74 Any Aboriginal right not delegated to the Crown is absolved to First Nations. Many Canadians of European descent adopt the notion that First Nations peoples are a conquered people and that their predicaments are a product of war and refusal to assimilate with Europeans in post confederation. However, these outstanding beliefs are irrational when such familiar treaties as those leading to the Royal Proclamation 1763 and 'Numbered Treaties' (which can only be established by two self-governing nations) outline each nations jurisdictions and system of coexistence. It is incredibly puzzling why First Nations peoples are no longer treated as equals. As Canada's first founding peoples, First Nations fought to defend the Crown, its colonists and land from invaders, assist in the institution of federalism in Canada, ${ }^{75}$ and First Nations' treaties first pioneered a system of equalization formulas that are now familiar in Canadian federalism. The negotiation of supplements and compensation for the loss of land and governing autonomy were the basis for these payments. ${ }^{76}$ Other terms of the treaty federalism asserted: 1) protection of Aboriginal rights, 2) distribution of shared jurisdictions, 3) territorial management, 4) promotion of human liberties and rights, and 5) instituting treaty delegations. ${ }^{77}$ Andrew Bear Robe argues that the initial conduct over land treaties can be applied to the sharing of

\footnotetext{
72 Ibid; 269.

${ }^{73}$ Andrew Bear Robe, 'Treaty Federalism - A Concept for the Entry of First Nations into the Canadian Federation and Commentary on the Canadian Unity Proposals', (Gleichen, AB: Andrew Bear Robe and Siksika Indian Government Division), Apr. 30, 1992. Final Version, p. 27.

${ }^{74}$ James Youngblood Henderson, 'Empowering Treaty Federalism', (Saskatchewan Law Review vol. 58, 1994), p. 314.

75 The Iroquois Six Nations Confederacy became an earmark example for the founding fathers in the United States to build a nation on the principle of divided jurisdictions. For more information see: Gina van den Burg, "To Whom Do We Give Thanks?: The Influence of the Iroquois Six Nation and the Puritans on the Formation of an American Federal State" (Master's Paper, McMaster University, 2004).

${ }^{76}$ Ibid; p. 267.

77 James Youngblood Henderson, 'Empowering Treaty Federalism', (Saskatchewan Law Review vol. 58, 1994), p. 250-251.
} 
sovereignty. ${ }^{78}$ Just as lands and resources were divided between Aboriginals and Europeans through treaties, jurisdictions can be shared and divided by the same method.

There is a misperception that treaty federalism is equated with a third order of government within Canada. Rather, treaty federalism advocates for equal status with the provinces where First Nations share a similar relationship with the federal government as do the provinces. It also infers that First Nations manage equivalent jurisdictions as the provinces albeit within their own territorial boundaries. Treaty federalism does not imply the disruption of the existing division of powers delineated in the Canadian Constitution, more accurately "each jurisdiction maintains their own". ${ }^{79}$ This arrangement strictly necessitates each province to refrain from intervening in First Nations' governing and punitive affairs and act intra vires.

Although Indian Affairs is a federal matter, it progressively surrendered responsibility over Aboriginal land to the provinces as well as imposing provincial laws on reserves. Accompanying these actions, confusion ensued over which governments were fiscally responsible for First Nations' monetary policy creating fiscal battles between governments. ${ }^{80}$ Implementing the treaty orders will quickly resolve this dilemma by clearly defining the jurisdictions and maintaining the historical relationship with the Crown and federal government — not directly with the provinces. As Henderson explains, Aboriginals "are the only peoples that the federal government has an exclusive and continuing constitutional obligation to serve, while the provinces serve the colonialists". ${ }^{81}$ According to the Sparrow decision, the courts declared the Aboriginals are constitutionally protected from provincial interference in First Nations affairs.

Reexamining Appendix A, we can compare the jurisdictions of the Siksika First Nation ${ }^{82}$ and the responsibilities required to properly function as a self-governing society. Their actions can formulate an example for other First Nations to proceed in achieving control over their own destiny. Under the Siksika's proposed arrangements they will have full control over:

\footnotetext{
${ }^{78}$ Andrew Bear Robe, 'Treaty Federalism - A Concept for the Entry of First Nations into the Canadian Federation and Commentary on the Canadian Unity Proposals', (Gleichen, AB: Andrew Bear Robe and Siksika Indian Government Division), Apr. 30, 1992. Final Version, p. 11.

79 Ibid; p. 20.

${ }^{80}$ James Youngblood Henderson, 'Empowering Treaty Federalism', (Saskatchewan Law Review vol. 58, 1994), p. 279.

${ }^{81}$ Ibid., 307.

${ }^{82}$ Ths Siksika First Nation are an Aboriginal band consisting of approximately 4200 members. They are also known by their English name as the Blackfoot Tribe or Plains People. They are located primarily in the province of Alberta, an hour a way from Calgary. They have been campaigning the Canadian government to enforce treaty obligations, recognize their self-governing capacity and remove them from the confines of the Indian Act.
} 


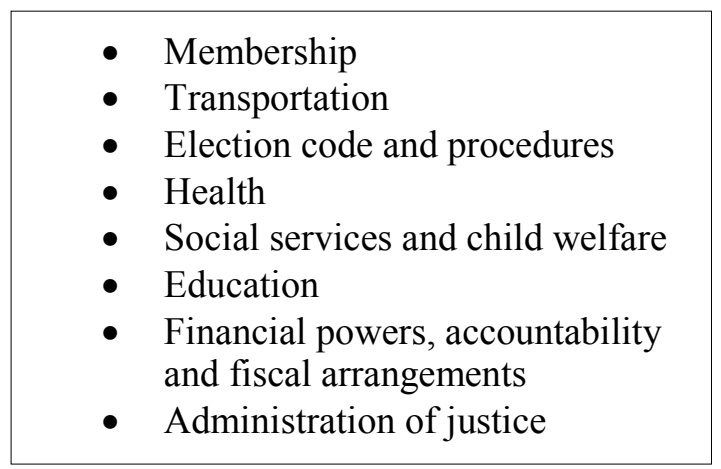

- Land title, land use and land management

- Renewable and non-renewable resources

- Environment

- Water

- Public works and undertakings

- Language, heritage and culture

- Local trade and commerce

Source: Andrew Bear Robe, 'Treaty Federalism-A Concept for the Entry of First Nations into the Canadian Federation and Commentary on the Canadian Unity Proposals', (Gleichen, AB: Andrew Bear Robe and Siksika Indian Government Division), Apr. 30, 1992. Final Version, p. 27.

We can observe that these responsibilities are consistent with provincial powers and are the essential building blocks for any society to function. The Sisksika Nation has become a positive example for First Nations by demonstrating that Aboriginal peoples can successfully accomplish and maintain self-government. Furthermore, the recognition of First Nations' jurisdictions will eliminate the offensive position of subordination and be perceived as equal partners in confederation.

In essence, treaty federalism facilitates guidelines on how Aboriginal governance policy should be addressed and outlines the roles of particular actors in the process of Aboriginal governance policy; thus detailing the relationship between the federal government and First Nations. Implementing treaty federalism will unquestionably help but not completely resolve all of Aboriginals' tribulations. Nevertheless, it is a significant step forward for rectifying repeated past wrongs on First Nations peoples. It will initiate greater responsibility and allow Aboriginals to develop policy that best suits their cultural distinctness. It is still crucial for the federal government to devise new Aboriginal governing policy since it is clearly stated in treaties exactly how the government should proceed: principally, that the government should refrain from interfering in First Nations' affairs. Moreover, Aboriginals can establish their own policies (together with reaffirming their self-government practices) in accordance with their treaties.

\section{$\underline{\text { Conclusion }}$}

Aboriginal governance policy may take an interesting turn with the new government in office. Paul Martin has little affiliation with DIAND so this could be viewed as positive or as a potential problem-positive in the sense that more consultation and devolution of powers to band 
governments may be feasible or problematic in reference to Aboriginal governing affairs being on the list of low priorities. Throughout this policy's history, the direction of Aboriginal governance policy alternates between these two views. Most of its history is problematic. Since the Royal Proclamation there have been shifts between devolution of responsibilities to Aboriginals, to paternalism with the Indian Act, a return to devolution with the entrenchment of Aboriginal rights in the 1982 Constitution Act, and then back to paternalism with the recent First Nations Governance Act. Frequently the shifts are attributed to the leaders that are in office at the time. Pierre Trudeau voluntarily followed a paternalistic approach, while Mulroney relinquished authority to First Nations. Chrétien resumed Trudeau's agenda of paternalism.

An increasing demand for recognition of particular governing rights by Aboriginal political organizations attracted attention from several different policy actors. Almost all policy actors involved in the policy process advocate for greater self-governing powers for First Nations and less interference from the federal government in their affairs. Consistently the Liberal government has ignored many of these requests and continues the path of paternalism and assimilation.

Why the government maintains this role is a matter of contrasting political thought. The practice of Canadian liberal democracy is unsupportive of Aboriginal special rights and misunderstands the precepts to First Nation political culture. In addition, recognition and reversal of previous assimilationist policies may be costly to the government and so politicians and policy-makers follow the path they are most comfortable with regardless of its implications on First Nations peoples; a clear example of path dependency theory. This route will persist unless more knowledgeable public servants are available to defend or influence Aboriginal governance policy.

To offset the depletion of expert public servants in the area of Aboriginal governance policy, greater consultation is required between First Nations leaders and the Canadian governments. Inclusion of First Nations in the development of public policy by means of problem definition and setting goals is crucial. Governments do not necessarily have the best interests of First Nations in mind or understand their target population when developing policies and require Aboriginals' input from the outset. There has fortunately been a positive movement towards increased consultation, yet significant defects linger in recent policies, like the FNGA, that have remained unchanged. It is questionable whether greater representation within Canadian institutions will compensate for the lack of consultation. Some scholars argue that there is a lack 
of representation for Aboriginals to influence policy; others insist that the less representation in Canadian institutions is for the better. The latter group believes participation in 'foreign' institutions is a method of consenting to assimilation, but also it decreases the influence of First Nations political organizations. The widely supported solution to Aboriginal governance policy is to implement treaty federalism. All policy formation and proceedings will be derived from treaties and assist band governments to re-instate their overdue governing powers.

Predictions over the path of Aboriginal governance policy are blurred at best. What can be seen in the future is that greater attention will be bestowed on Aboriginal self-government as a solution to the poor social and economic conditions ubiquitous in First Nations communities. In time, with the expectation of several more controversial policies, Aboriginals will finally succeed in developing their own independent policies within their own fully autonomous government institutions. 
Appendix A:

Aboriginal Jurisdictions

\begin{tabular}{|c|c|c|}
\hline $\begin{array}{c}\text { List One } \\
\text { Matters Central to Self- } \\
\text { Government }\end{array}$ & $\begin{array}{c}\text { List Two } \\
\text { Matters not Integral } \\
\text { and Internal } \\
\end{array}$ & $\begin{array}{c}\text { List Three } \\
\begin{array}{c}\text { Matters not Subject to } \\
\text { Negotiation }\end{array} \\
\end{array}$ \\
\hline $\begin{array}{l}\text {-elections } \\
\text {-structures } \\
\text {-membership } \\
\text {-marriage } \\
\text {-child welfare } \\
\text {-language, culture } \\
\text { - local taxation } \\
\text {-education } \\
\text { - health } \\
\text { - monies } \\
\text { - hunting, fishing } \\
\text { - law administration } \\
\text {-policing } \\
\text { - housing } \\
\text {-property } \\
\text {-public works } \\
\text { - local transportation } \\
\text { - business licensing and } \\
\text { regulation } \\
\text {-land management } \\
\text {-agriculture }\end{array}$ & $\begin{array}{l}\text {-divorce } \\
\text {-labour/training } \\
\text {-administration of laws of } \\
\text { other jurisdictions } \\
\text {-penitentiaries and parole } \\
\text {-environmental protection and } \\
\text { assessment } \\
\text {-fisheries co-management } \\
\text {-gaming } \\
\text { - emergency preparedness } \\
\text {-migratory birds co- } \\
\text { management }\end{array}$ & $\begin{array}{l}\text {-immigration } \\
\text {-international trade } \\
\text {-management and } \\
\text { regulation of national } \\
\text { economy } \\
\text {-national and criminal law } \\
\text { - health and safety of } \\
\text { Canadians } \\
\text { - broadcasting } \\
\text {-national transportation } \\
\text {-postal } \\
\text {-navigation }\end{array}$ \\
\hline
\end{tabular}

Source: J. Kaufman and F. Roberge, Aboriginal Governance in the Canadian Federal State 2015, (Kingston: Institute of Intergovernmental Relations, Working Paper 2003), p. 53.

Appendix B:

First Nations Governments' Level of Financial Autonomy Limited Discretion Program Specific

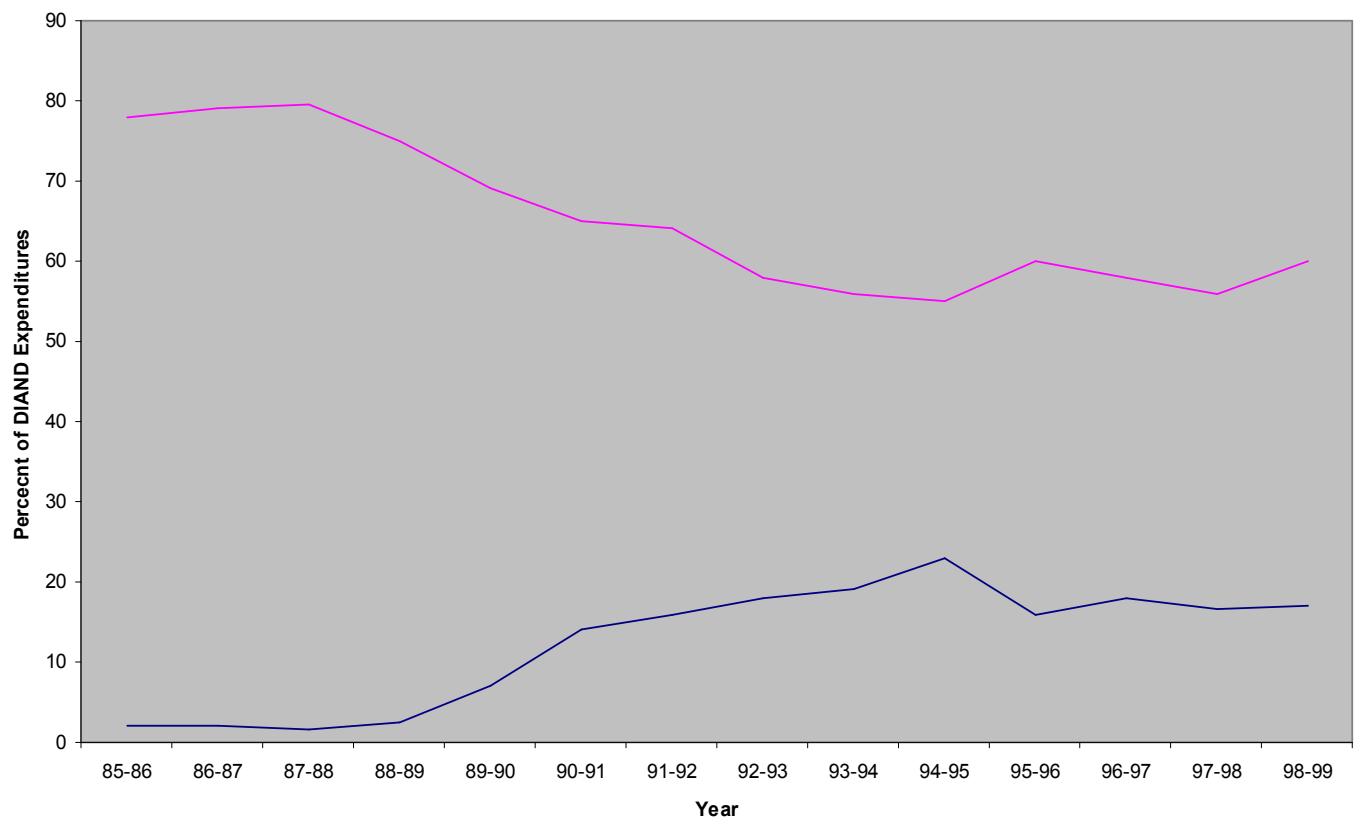


Appendix C:

Policy Map and Relationship between Policy Actors

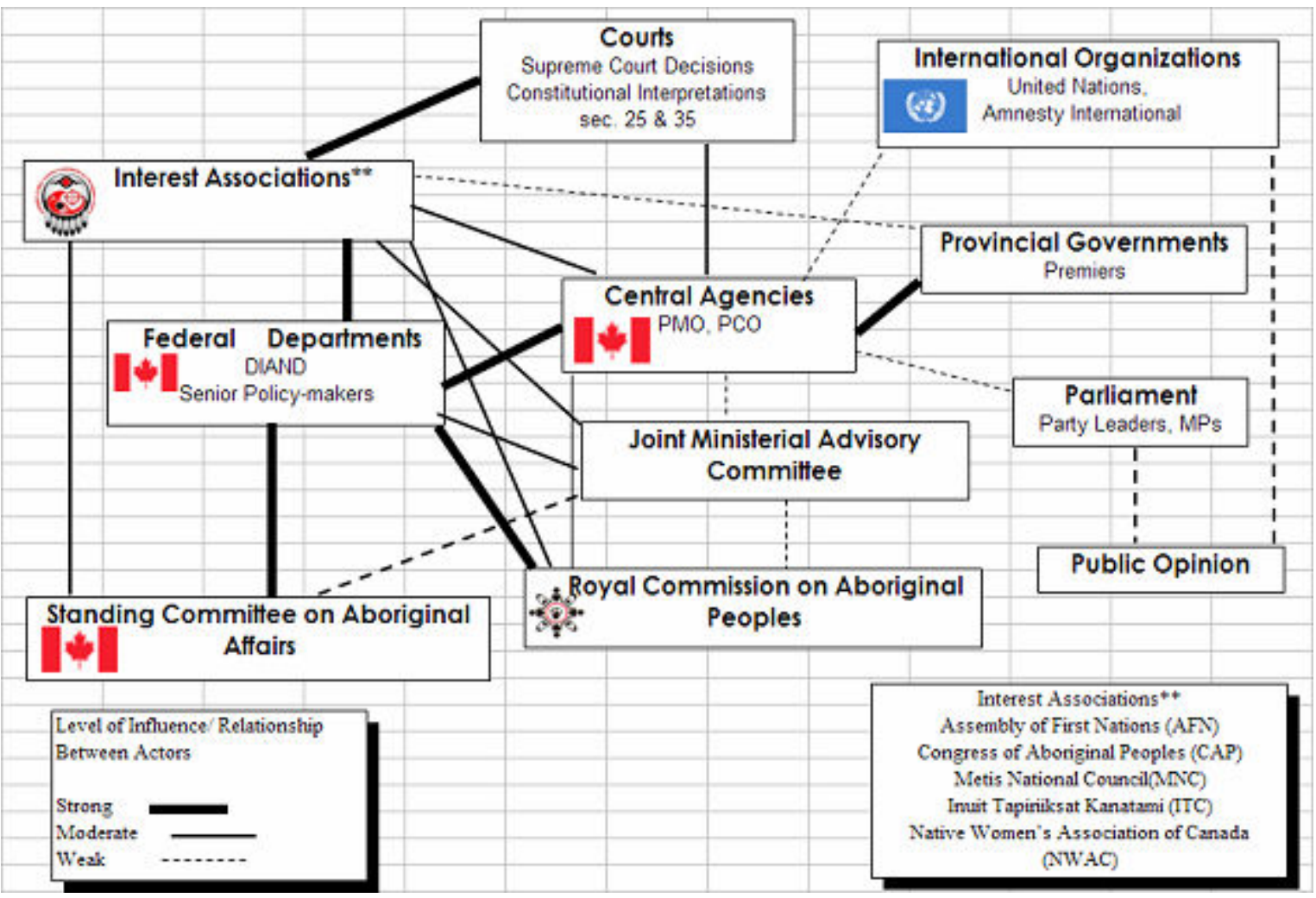


Appendix D:

Divergent Political Cultures

\begin{tabular}{|c|c|}
\hline Eurocentric & Aboriginal \\
\hline Money as "capital" & Nature as "capital" \\
\hline Democratic or autocratic decision-making & Consensus decision-making \\
\hline $\begin{array}{l}\text { Alienation from the process of government } \\
\text { on a day-to-day level }\end{array}$ & $\begin{array}{l}\text { Active participation in the process of } \\
\text { government on a day-to-day level }\end{array}$ \\
\hline Power concentrated in the hands of a few & Power broadly based \\
\hline Strong ethic of direct leadership & Strong ethic of collective leadership \\
\hline Work emphasizes material gain & Work emphasizes spiritual gain \\
\hline Individual ownership & Collective ownership \\
\hline Ethic of competition & Ethic of cooperation \\
\hline Work-related stresses & Stress associated with external variables \\
\hline $\begin{array}{l}\text { Land/means of production can be owned } \\
\text { individually }\end{array}$ & $\begin{array}{l}\text { Land/means of production are held } \\
\text { collectively }\end{array}$ \\
\hline $\begin{array}{l}\text { Legal titles and deeds can be held } \\
\text { individually }\end{array}$ & No such concept \\
\hline Land belongs to "us" & "we" belong to the land \\
\hline $\begin{array}{c}\text { Success measured by accumulation } \\
\text { economic }\end{array}$ & Success measured by peer review \\
\hline $\begin{array}{l}\text { Profound belief that economic change can } \\
\text { be imposed from an outside society }\end{array}$ & $\begin{array}{l}\text { Profound belief that economic change can } \\
\text { only be accomplished from within society }\end{array}$ \\
\hline Ethic of individualism & Ethic of "kin-ism" \\
\hline Permanent institutions & Fluidity of institutions \\
\hline $\begin{array}{l}\text { Deviance is punished by confinement } \\
\text { within society }\end{array}$ & Deviance is punished by exile from society \\
\hline $\begin{array}{c}\text { Problems are isolated away from society in } \\
\text { general }\end{array}$ & $\begin{array}{l}\text { Problems are dealt with at a community } \\
\text { level }\end{array}$ \\
\hline
\end{tabular}

Source: Unkown 
Appendix E:

Competing Visions of the Treaty Process

\begin{tabular}{|c|c|c|}
\hline & $\begin{array}{r}\text { Federal and Provincial } \\
\text { Governments }\end{array}$ & First Nations \\
\hline $\begin{array}{l}\text { Status and Relationship of } \\
\text { the Parties }\end{array}$ & $\begin{array}{l}\text { Representatives of the } \\
\text { Crown meeting with } \\
\text { minorities within Canada }\end{array}$ & $\begin{array}{l}\text { Equal peoples and } \\
\text { governments in status, } \\
\text { nation to nation }\end{array}$ \\
\hline Purposes of Treaty Process & $\begin{array}{l}\text { To define and enumerate } \\
\text { rights and protect them } \\
\text { under the Constitution } \\
\text { To bring certainty to all } \\
\text { parties and some } \\
\text { compensation and } \\
\text { capacity-building to First } \\
\text { Nations }\end{array}$ & $\begin{array}{l}\text { To work out relations of } \\
\text { mutual understanding of } \\
\text { identities and mutual } \\
\text { sharing of powers, land } \\
\text { and resources among } \\
\text { equals }\end{array}$ \\
\hline $\begin{array}{l}\text { Scope and Nature of } \\
\text { Treaties as Documents }\end{array}$ & $\begin{array}{l}\text { Treaties are large, once- } \\
\text { and-for-all agreements } \\
\text { dealing with matters of } \\
\text { jurisdictions, authorities } \\
\text { and governance }\end{array}$ & $\begin{array}{l}\text { Treaties are specific, short } \\
\text { term, and renewable } \\
\text { agreements aimed at } \\
\text { specific problems }\end{array}$ \\
\hline Intended Results & $\begin{array}{l}\text { A full and final settlement } \\
\text { of outstanding claims, } \\
\text { obligations, and rights. }\end{array}$ & $\begin{array}{l}\text { An on-going/continuous } \\
\text { process of cross-cultural } \\
\text { dialogue and review and } \\
\text { adjustments of treaties. }\end{array}$ \\
\hline
\end{tabular}

Source: Frances Abele \& Michael J. Prince, Aboriginal Governance and Canadian Federalism: A To-Do List for Canada, in Rocher \& Smith (ed) New Trends in Canadian Federalism (Peterborough: Broadview Press, 2003 ), p. 151. 